\title{
Ecological analyses and case-control studies of gastric cancer and leukaemia in relation to DBCP in drinking water in Fresno County, California
}

\author{
O WONG, R W MORGAN, M D WHORTON, NANCY GORDON, LEEKA KHEIFETS
}

From Environmental Health Associates, Inc, Oakland, California 94607, USA

\begin{abstract}
Through ecological analyses and case-control studies, the possible relation of gastric cancer and leukaemia to dibromochloropropane (DBCP) contamination of drinking water in Fresno County, California, has been examined. The ecological analyses examined the correlation between gastric cancer and leukaemia (including the lymphatic varieties), mortality rates, and DBCP concentrations in drinking water by census tract in Fresno County, 1960-83. No correlation was found between gastric cancer or leukaemia and DBCP. The gastric cancer case-control study consisted of 263 deaths from gastric cancer in the county, 1975 to mid-1984, and 1044 controls, using information on residential history and occupation of both cases and controls. Analyses were based on residence at death, as well as one and ten years before death. The case-control study did not find any relation between gastric cancer and DBCP in drinking water. Hispanics in the county were found to experience a relative risk of gastric cancer of $2 \cdot 77$, compared with non-Hispanics. A similar casecontrol study consisting of 259 cases of leukaemia and 1161 controls found no relation between all leukaemia or lymphatic leukaemia and DBCP in drinking water. Farm workers, however, do appear to have an increased risk of leukaemia.
\end{abstract}

This investigation arose out of concern generated from a report from the California Department of Health Services in 1982, ${ }^{1}$ which reported an ecological correlation between water contaminated with dibromochloropropane (DBCP) and mortality rates for gastric cancer and leukaemia in Fresno County, California, from 1970 to 1979 . The authors suggested that further investigations, including case-control studies should be undertaken.

To examine further the issue of DBCP contamination in Fresno County and the risk of gastric cancer for the extended period 1960-83 we conducted an ecological correlation analysis of water contamination with gastric cancer, controlling for certain demographic variables, and using the best available water quality data. In addition, we also conducted a casecontrol investigation of gastric cancer, using all deaths from gastric cancer in the county, 1975 to 1985 . A similar, parallel study of leukaemia was also conducted and the results are also included in this report.

\section{Materials and methods}

WATER QUALITY DATA

A previous paper summarises the water quality data

Accepted 8 August 1988 used for both our ecological correlation and the casecontrol studies. ${ }^{2}$ For the present study, it was necessary to derive water quality estimates for each census tract. The task was complicated because a single census tract may be served by more than one system, each system usually has more than one well, and a single well may have several episodes of testing for various contaminants. We calculated a series of weighted averages for each contaminant in each census tract, using production figures for each well as the weighing factor. Water quality data were derived from a total of 14861 laboratory reports, although the majority did not report on all contaminants. Mean DBCP concentrations ranged from $0.0041 \mathrm{ppb}$ to $5.7543 \mathrm{ppb}$ among the census tracts, with varying amounts of nitrates and arsenic as well. To examine the correlation between contamination and mortality, we divided the census tracts into seven contamination strata.

\section{ECOLOGICAL ANALYSES}

The ecological correlation analyses relied on the 1960, 1970, and 1980 census data of Fresno County. The State of California Department of Finance supplied data at the census tract level for Hispanic ethnicity stratified by age and sex, and the United States Bureau of the Census provided information regarding Spanish 
Table 1 Distribution of residential history completion rates by case and control status

\begin{tabular}{|c|c|c|c|c|c|c|c|}
\hline \multirow[b]{2}{*}{ Case/control status } & \multicolumn{2}{|c|}{ Complete } & \multicolumn{2}{|c|}{ Refusal } & \multicolumn{2}{|c|}{ No contact } & \multirow{2}{*}{$\begin{array}{l}\text { Total } \\
\text { No }\end{array}$} \\
\hline & No & Row\% & No & Row\% & No & Row\% & \\
\hline $\begin{array}{l}\text { Cases } \\
\text { Controls }\end{array}$ & $\begin{array}{l}203 \\
804\end{array}$ & $\begin{array}{l}77.2 \% \\
77.0 \%\end{array}$ & $\begin{array}{r}\text { Gastric c } \\
7 \\
26\end{array}$ & $\begin{array}{l}2 \cdot 7 \% \\
2 \cdot 5 \%\end{array}$ & $\begin{array}{r}53 \\
214\end{array}$ & $\begin{array}{l}20 \cdot 2 \% \\
20.5 \%\end{array}$ & $\begin{array}{r}263 \\
1044\end{array}$ \\
\hline Total & 1007 & $77.0 \%$ & 33 & $2 \cdot 5 \%$ & 267 & $20.4 \%$ & 1307 \\
\hline $\begin{array}{l}\text { Cases } \\
\text { Controls }\end{array}$ & $\begin{array}{l}225 \\
871\end{array}$ & $\begin{array}{l}76 \cdot 3 \% \\
75 \cdot 0 \%\end{array}$ & $\begin{array}{c}\text { Leukae } \\
10 \\
30\end{array}$ & $\begin{array}{l}3.4 \% \\
2.6 \%\end{array}$ & $\begin{array}{r}60 \\
260\end{array}$ & $\begin{array}{l}20 \cdot 3 \% \\
22 \cdot 4 \%\end{array}$ & $\begin{array}{r}296 \\
1161\end{array}$ \\
\hline Total & 1096 & $75 \cdot 3 \%$ & 40 & $2 \cdot 7 \%$ & 320 & $22 \cdot 0 \%$ & 1456 \\
\hline
\end{tabular}

surnames. We eventually stratified census tract population data by race (black and non-black), ethnicity (Hispanic and non-Hispanic), age (five year groups), and sex. On the recommendation of the California Census Data Center, we calculated denominators between census years by straight line interpolation, using the two adjacent census years.

The Vital Statistics Office of the State of California supplied computer tapes for Fresno County for the years 1960 to 1983 . From those tapes and subsequently retrieved death certificates, our nosologist verified all deaths from gastric cancer and leukaemia to provide numerators. Death rate calculations by DBCP category were adjusted for race, age, sex, and for years 1970-83, Hispanic ethnicity, using direct standardisation with Fresno County as the standard population.

The analyses used the seven categories of exposure described earlier. Each analysis was done in five calendar year groupings (1960-4, 1965-9, 1970-4, 1975-9), except 1980-3, a four year group.

\section{CASE-CONTROL STUDIES}

For the case-control studies, we identified potential cases from State of California computer tapes of deaths in Fresno County from 1975 to mid-1984. Cases were defined as all individuals whose underlying cause of death was gastric cancer or leukaemia, 1975mid 1984, where the death certificate indicated usual residence of the decedent as Fresno County and named the supplier of information (informant) for the certificate information.

Each Fresno County resident who died during the same period was eligible for the control group, except when the death certificate mentioned gastric cancer or leukaemia. As with the cases, for each eligible control the usual residence as identified on the death certificate had to be Fresno County and a spouse or other contact person (informant) had to be identified on the death certificate.

It was planned that each case would have at least three controls. This number was based on a considera- tion of both statistical efficiency and cost. Three controls per case gives reasonable power, whereas anf additional controls provide diminishing returns for effort expended. In addition, the same controls were used in both the gastric cancer and the leukaemia caseio control studies. The following is a detailed description of the control selection.

From a computer tape of all deaths in Fresno. County from 1975 to mid-1984 we identified all deaths from gastric cancer and leukaemia and then stratifie them by age, race, and year. For each stratum, wळ randomly selected controls equalling three times the number of cases of gastric cancer or leukaemiaa whichever was the greater. These procedures produceef a total of 263 cases of gastric cancer and 148 corresponding controls. For leukaemia, 259 cases î̀ं 1161 controls were identified. The number of gastrie cancer controls was slightly lower than leukaemif controls because of the age difference between the cases of gastric cancer and leukaemia.

Once cases and controls were selected, we retrievee copies of their death certificates to verify the coding of the underlying cause of death. After that, we began te collect residential histories and occupations.

Research staff doing follow up and interviewing were unaware of the case or control status of the decedent. As stated earlier, for each case of leukaemia gastric cancer, or control we attempted to obtain complete residential history. We used regular mail registered mail, telephone, and a retail credit organis ation to locate either the original informant or $\$$ satisfactory substitute. Where no informant could bo found, we attempted to ascertain the decedent'sprevious residential history through city directories and retail credit bureaux. For purpose of analysis, we used the address at time of death, one year before, an\& ten years before. Each address was converted to botk water system and census tract as bases for assigning water quality estimates.

For the gastric cancer case-control study, we्ల obtained complete (10 year) residential histories on $1007(77 \%)$ of all subjects. There were only about $2 \%$ 
Table 2 Deaths from gastric cancer, annual death rates per 100000 (adjusted for age, sex, and race), and correlation coefficients of census tracts by seven categories of DBCP concentration in drinking water, Fresno County

\begin{tabular}{|c|c|c|c|c|c|c|c|c|c|c|}
\hline \multirow[b]{2}{*}{$D B C P$ concentration ( $p p b)$} & \multicolumn{2}{|l|}{$1960-4$} & \multicolumn{2}{|l|}{$1965-9$} & \multicolumn{2}{|l|}{$1970-4$} & \multicolumn{2}{|l|}{$1975-9$} & \multicolumn{2}{|l|}{$1980-3$} \\
\hline & Deaths & Rates & Deaths & Rates & Deaths & Rates & Deaths & Rates & Deaths & Rates \\
\hline $\begin{array}{l}<0.010 \\
0 \cdot 010-0 \cdot 100 \\
0 \cdot 100-0.200 \\
0 \cdot 200-0.500 \\
0 \cdot 500-1.000 \\
1.000-3.000 \\
>3.000\end{array}$ & $\begin{array}{r}9 \\
119 \\
7 \\
21 \\
3 \\
24 \\
10\end{array}$ & $\begin{array}{r}13 \cdot 57 \\
10 \cdot 13 \\
16 \cdot 51 \\
10 \cdot 59 \\
6 \cdot 40 \\
9 \cdot 33 \\
19 \cdot 54\end{array}$ & $\begin{array}{r}0 \\
104 \\
13 \\
19 \\
5 \\
26 \\
5\end{array}$ & $\begin{array}{r}0 \\
8 \cdot 52 \\
8.97 \\
9 \cdot 66 \\
7 \cdot 05 \\
10 \cdot 72 \\
10 \cdot 79\end{array}$ & $\begin{array}{r}8 \\
102 \\
7 \\
17 \\
8 \\
20 \\
5\end{array}$ & $\begin{array}{r}9 \cdot 32 \\
7.71 \\
3 \cdot 65 \\
7 \cdot 44 \\
11 \cdot 30 \\
7 \cdot 19 \\
7 \cdot 35\end{array}$ & $\begin{array}{r}9 \\
100 \\
13 \\
20 \\
6 \\
22 \\
6\end{array}$ & $\begin{array}{r}8 \cdot 59 \\
7 \cdot 72 \\
5 \cdot 78 \\
7.62 \\
8.45 \\
6 \cdot 90 \\
10 \cdot 17\end{array}$ & $\begin{array}{r}6 \\
73 \\
10 \\
12 \\
0 \\
13 \\
4\end{array}$ & $\begin{array}{r}7.82 \\
6.05 \\
4 \cdot 67 \\
5 \cdot 14 \\
0 \\
4.38 \\
7 \cdot 32\end{array}$ \\
\hline $\begin{array}{l}\text { Correlation coefficient (rate } \\
\text { and DBCP) } \\
\text { p Value }\end{array}$ & & $\begin{array}{l}0.526 \\
0.23\end{array}$ & & $\begin{array}{l}0.481 \\
0.27\end{array}$ & & $\begin{array}{c}-0.027 \\
0.95\end{array}$ & & $\begin{array}{l}0.661 \\
0.11\end{array}$ & & $\begin{array}{l}0.26 \\
0.64\end{array}$ \\
\hline
\end{tabular}

refusals and $20 \%$ "no contacts" in both cases and controls (table 1). We examined the completion rates among the cases of gastric cancer and the controls by several variables. The completion rates did not differ between the two groups.

The response pattern of cases of leukaemia and controls (table 1) was similar to that found for the gastric cancer study except for a slightly poorer response rate among young adults. The reason for the poorer response is not clear. Response rates for cases of leukaemia and controls were similar.

We computed relative risk (approximated by odds ratio) for each relevant factor. We analysed dichotomous variables (Hispanic $v$ non-Hispanic) by the Mantel-Haenszel chi-squared procedure, ${ }^{3}$ and polychotomous variables (level of exposure to DBCP) by an extension of that procedure. ${ }^{4}$ To examine the data for possible interaction among the variables, we used the multiple logistic regression technique. ${ }^{56}$

\section{Results}

ECOLOGICAL ANALYSES

As explained earlier, we used seven categories of water contamination. Census tracts with higher DBCP concentrations were in a lower socioeconomic class and had a higher proportion of Hispanics. Over the time spanned by the three censuses, the proportion of Hispanics in the county increased considerably. Furthermore, the increase was not uniform across census tracts within the county. This means that each period must be analysed separately and no single estimate for the Hispanic proportion can be applied throughout the analyses.

Table 2 shows the adjusted gastric cancer mortality by the seven categories of exposure. The analysis shows no significant correlation between gastric cancer mortality and DBCP concentrations. The 1965-9 rates seems to show a slight trend but the correlation was not statistically significant $(p=0 \cdot 27)$.

Table 3 displays the data for all leukaemias, using seven contamination categories, whereas table 4 examines the lymphatic leukaemia subset. The data do not show any trend of increasing risk with category of exposure.

We also conducted similar correlation analyses for nitrates and arsenic content of the water. The results

Table 3 Deaths from leukaemia, annual death rates per 100000 (adjusted for age, sex, and race), and correlation coefficients of census tracts by seven categories of DBCP concentration in drinking water, Fresno County

\begin{tabular}{|c|c|c|c|c|c|c|c|c|c|c|}
\hline \multirow[b]{2}{*}{$D B C P$ concentration ( $p p b)$} & \multicolumn{2}{|l|}{$1960-4$} & \multicolumn{2}{|l|}{$1965-9$} & \multicolumn{2}{|l|}{$1970-4$} & \multicolumn{2}{|l|}{$1975-9$} & \multicolumn{2}{|l|}{$1980-3$} \\
\hline & Deaths & Rates & Deaths & Rates & Deaths & Rates & Deaths & Rates & Deaths & Rates \\
\hline $\begin{array}{l}<0.010 \\
0 \cdot 010-0 \cdot 100 \\
0 \cdot 100-0 \cdot 200 \\
0 \cdot 200-0.500 \\
0 \cdot 500-1 \cdot 000 \\
1 \cdot 000-3 \cdot 000 \\
>3 \cdot 000\end{array}$ & $\begin{array}{r}4 \\
81 \\
4 \\
13 \\
3 \\
10 \\
3\end{array}$ & $\begin{array}{l}5 \cdot 83 \\
7 \cdot 00 \\
4 \cdot 65 \\
6 \cdot 25 \\
5 \cdot 30 \\
4 \cdot 05 \\
6 \cdot 77\end{array}$ & $\begin{array}{r}4 \\
99 \\
7 \\
13 \\
4 \\
26 \\
6\end{array}$ & $\begin{array}{r}5 \cdot 03 \\
8.09 \\
4.72 \\
5.98 \\
6.81 \\
11 \cdot 30 \\
10.27\end{array}$ & $\begin{array}{r}8 \\
74 \\
16 \\
10 \\
4 \\
11 \\
2\end{array}$ & $\begin{array}{l}8 \cdot 03 \\
5 \cdot 77 \\
7 \cdot 82 \\
4 \cdot 55 \\
5 \cdot 95 \\
4 \cdot 31 \\
4 \cdot 03\end{array}$ & $\begin{array}{r}4 \\
84 \\
13 \\
14 \\
7 \\
19 \\
2\end{array}$ & $\begin{array}{l}3 \cdot 73 \\
5 \cdot 98 \\
6 \cdot 48 \\
5 \cdot 84 \\
8 \cdot 39 \\
6 \cdot 64 \\
2 \cdot 96\end{array}$ & $\begin{array}{r}5 \\
73 \\
26 \\
25 \\
6 \\
19 \\
5\end{array}$ & $\begin{array}{r}6 \cdot 10 \\
6 \cdot 15 \\
12 \cdot 97 \\
12 \cdot 00 \\
6 \cdot 95 \\
8 \cdot 16 \\
8 \cdot 27\end{array}$ \\
\hline $\begin{array}{l}\text { Correlation coefficient (rate } \\
\text { and DBCP) } \\
\text { p Value }\end{array}$ & & $\begin{array}{l}0.179 \\
0.70\end{array}$ & & $\begin{array}{l}0.716 \\
0.07\end{array}$ & & $\begin{array}{c}-0.654 \\
0.11\end{array}$ & & $\begin{array}{c}-0.489 \\
0.27\end{array}$ & & $\begin{array}{r}-0.07 \\
0.87\end{array}$ \\
\hline
\end{tabular}


Table 4 Deaths from lymphatic leukaemia, annual death rates per 100000 (adjusted for age, sex, and race), and correlation $\overline{\bar{B}}$ coefficients of census tracts by seven categories of DBCP concentration in drinking water, Fresno County

\begin{tabular}{|c|c|c|c|c|c|c|c|c|c|c|}
\hline \multirow[b]{2}{*}{$D B C P$ concentration (ppb) } & \multicolumn{2}{|l|}{$1960-4$} & \multicolumn{2}{|l|}{$1965-9$} & \multicolumn{2}{|l|}{$1970-4$} & \multicolumn{2}{|l|}{$1975-9$} & \multicolumn{2}{|l|}{$1980-3$} \\
\hline & Deaths & Rates & Deaths & Rates & Deaths & Rates & Deaths & Rates & Deaths & Rate \\
\hline $\begin{array}{l}<0 \cdot 010 \\
0 \cdot 010-0 \cdot 100 \\
0 \cdot 100-0 \cdot 200 \\
0 \cdot 200-0.500 \\
0 \cdot 500-1 \cdot 000 \\
1 \cdot 000-3.000 \\
>3 \cdot 000\end{array}$ & $\begin{array}{r}2 \\
39 \\
1 \\
7 \\
2 \\
6 \\
1\end{array}$ & $\begin{array}{l}3 \cdot 27 \\
3 \cdot 40 \\
1 \cdot 28 \\
3 \cdot 38 \\
3 \cdot 61 \\
2 \cdot 44 \\
2 \cdot 34\end{array}$ & $\begin{array}{r}3 \\
40 \\
3 \\
7 \\
2 \\
10 \\
2\end{array}$ & $\begin{array}{l}3.05 \\
3.28 \\
1.91 \\
3.07 \\
3.54 \\
4.43 \\
3.06\end{array}$ & $\begin{array}{r}2 \\
22 \\
5 \\
1 \\
1 \\
4 \\
0\end{array}$ & $\begin{array}{l}2 \cdot 55 \\
1 \cdot 72 \\
2 \cdot 30 \\
0 \cdot 40 \\
2 \cdot 46 \\
1 \cdot 31 \\
0 \cdot 00\end{array}$ & $\begin{array}{r}1 \\
20 \\
8 \\
3 \\
2 \\
11 \\
0\end{array}$ & $\begin{array}{l}1.20 \\
1.39 \\
4.49 \\
1.45 \\
2.86 \\
3.88 \\
0.00\end{array}$ & $\begin{array}{r}1 \\
23 \\
7 \\
5 \\
5 \\
6 \\
2\end{array}$ & $\begin{array}{l}1.00 \mathrm{c} \\
1.91 \\
4.530 \\
2.41 \\
6.210 \\
2.610 \\
3.380\end{array}$ \\
\hline $\begin{array}{l}\text { Correlation coefficient (rate } \\
\text { and DBCP) } \\
\text { p Value }\end{array}$ & & $\begin{array}{c}-0.269 \\
0.56\end{array}$ & & $\begin{array}{l}0.210 \\
0.65\end{array}$ & & $\begin{array}{c}-0.697 \\
0.36\end{array}$ & & $\begin{array}{l}0.110 \\
0.82\end{array}$ & & $\begin{array}{l}0.11= \\
0.82 \mathrm{c}\end{array}$ \\
\hline
\end{tabular}

did not show any consistent pattern over time and are not presented here.

\section{CASE-CONTROL STUDY OF GASTRIC CANCER}

Table 5 displays race and ethnicity distributions by gastric cancer case and control status. Of the cases of gastric cancer, $30 \%$ were identified as Hispanics compared with only $15 \%$ of controls. In addition, the ages of cases of gastric cancer among those with Hispanic surnames tended to be younger than other cases $(15 \%$ Hispanic cases aged less than 50 compared with $3 \%$ in non-Hispanics; chi-squared $=10.85, p<$ 0.001 ). Table 6 examines the issue of Hispanic surname and occupation further. People with a Spanish surname had a relative risk of gastric cancer of 2.77 (p

Table 5 Distribution of race and ethnicity by case-control status

\begin{tabular}{|c|c|c|c|c|c|c|}
\hline & \multicolumn{6}{|c|}{ Gastric cancer } \\
\hline & \multicolumn{2}{|c|}{ Cases } & \multicolumn{2}{|c|}{ Controls } & \multicolumn{2}{|c|}{ Total } \\
\hline & No & $\%$ & No & $\%$ & No & $\%$ \\
\hline \multicolumn{7}{|c|}{ Race } \\
\hline $\begin{array}{l}\text { White } \\
\text { Non-white } \\
\text { Total }\end{array}$ & $\begin{array}{r}229 \\
34 \\
263\end{array}$ & $\begin{array}{r}87.07 \% \\
12.93 \% \\
100.00 \%\end{array}$ & $\begin{array}{r}922 \\
122 \\
1044\end{array}$ & $\begin{array}{r}88.31 \% \\
11 \cdot 69 \% \\
100 \cdot 00 \%\end{array}$ & $\begin{array}{r}1151 \\
156 \\
1307\end{array}$ & $\begin{array}{r}88.06 \% \\
11.94 \% \\
100.00 \%\end{array}$ \\
\hline \multicolumn{7}{|c|}{ Ethnicity } \\
\hline $\begin{array}{l}\text { Non-Hispanic } \\
\text { Hispanic } \\
\text { Total }\end{array}$ & $\begin{array}{r}185 \\
78 \\
263\end{array}$ & $\begin{array}{r}70.34 \% \\
29.66 \% \\
100.00 \%\end{array}$ & $\begin{array}{r}885 \\
159 \\
1044\end{array}$ & $\begin{array}{r}84.77 \% \\
15.23 \% \\
100.00 \%\end{array}$ & $\begin{array}{r}1070 \\
237 \\
1307\end{array}$ & $\begin{array}{r}81 \cdot 87 \% \\
18.13 \% \\
100.00 \%\end{array}$ \\
\hline
\end{tabular}

$<0.001)$. There was also a significant relative risk gastric cancer of $1.67(p=0.03)$ associated with farm workers. Nevertheless, when per cent Hispanics wàs controlled for, the relative risk for farm work decreased to 0.97 . Thus "farm worker" was not a ris\$ factor for gastric cancer by itself but appeared to reflect ethnicity.

Tables 7 and 8 present the relation between exposure to DBCP and risk of gastric cancer whereim the water quality was considered at time of death, one year before death, and ten years before death. Because complete information was not always available fifor residences before death, the numbers used for soms analyses were somewhat less than the group analyee for residence at death. For both the Mantel-Haensz procedure and the multiple logistic regression, relative risk is estimated by comparing people in the highes exposure group (>1.0 ppb), as defined in the DOH study, with those classified in the lowest exposure $(<0.05 \mathrm{ppb})$. In general, the Mantel-Haenszel and multiple logistic approaches gave comparaber. estimates, although there were some minor differences probably due to the use in the logistic model of actual rather than categorical data for some variables. Ais well as the point estimates of relative risk, table 7 gives upper and lower $95 \%$ confidence limits.

For the Mantel-Haenszel analysis, relative risks foo gastric cancer for the highest contamination leved ranged from 1.01 to 1.33 , with no statistically sig? nificant rises. Similarly, for the multiple logisti analysis, relative risks for gastric cancer for the higf

Table 6 Relative risk for gastric cancer in Fresno County by ethnicity and occupation

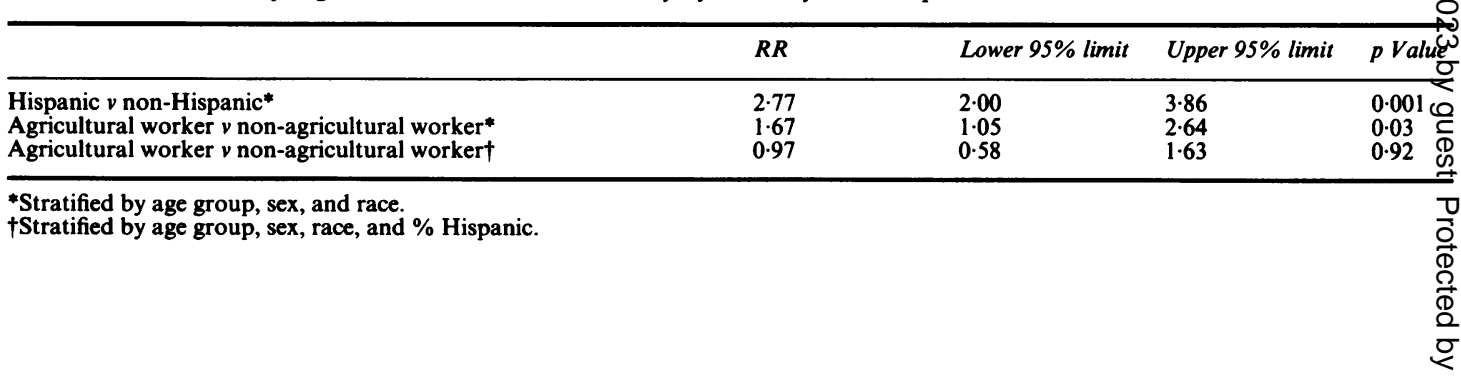


Table 7 Relative risk of gastric cancer for residents in the high DBCP exposure group compared with the low exposure group (using multiple logistic regression and Mantel-Haenszel procedure)

\begin{tabular}{|c|c|c|c|c|c|c|c|}
\hline \multirow[b]{2}{*}{$\begin{array}{l}\text { Time } \\
\text { of residence }\end{array}$} & \multirow[b]{2}{*}{$\begin{array}{l}\text { Water exposure } \\
\text { according to }\end{array}$} & \multicolumn{3}{|c|}{ Multiple logistic regression* } & \multicolumn{3}{|c|}{ Mantel-Haenszel proceduret } \\
\hline & & $\boldsymbol{R} R$ & $p$ & $\begin{array}{l}95 \% \text { Confidence } \\
\text { interval }\end{array}$ & $\boldsymbol{R} R$ & $p$ & $\begin{array}{l}95 \% \text { Confidence } \\
\text { interval }\end{array}$ \\
\hline $\begin{array}{l}\text { Death } \\
\text { One year before } \\
\text { Ten years before }\end{array}$ & $\begin{array}{l}\text { Census tract } \\
\text { Water system } \\
\text { Census tract } \\
\text { Water system } \\
\text { Census tract } \\
\text { Water system }\end{array}$ & $\begin{array}{l}1.05 \\
1.29 \\
1.01 \\
1.55 \\
1.00 \\
3.05\end{array}$ & $\begin{array}{l}\text { NS } \\
\text { NS } \\
\text { NS } \\
\text { NS } \\
\text { NS } \\
\text { NS }\end{array}$ & $\begin{array}{l}(0.74,1.49) \\
(0.62,2.69) \\
(0.67,1.54) \\
(0.68,3.56) \\
(0.66,1.53) \\
(0.95,9.84)\end{array}$ & $\begin{array}{l}1 \cdot 14 \\
1 \cdot 01 \\
1 \cdot 17 \\
1 \cdot 21 \\
1 \cdot 33 \\
1 \cdot 24\end{array}$ & $\begin{array}{l}\text { NS } \\
\text { NS } \\
\text { NS } \\
\text { NS } \\
\text { NS } \\
\text { NS }\end{array}$ & $\begin{array}{l}(0.66,1.96) \\
(0.48,2.12) \\
(0.63,2.17) \\
(0.53,2.80) \\
(0.70,2.53) \\
(0.49,3.12)\end{array}$ \\
\hline
\end{tabular}

*Variables used in model are: race, \% Hispanic, sex, age, agricultural worker grouping, actual exposure values for DBCP, arsenic, and nitrate.

†Stratified by race, \% Hispanic, sex, age group, and agricultural worker grouping.

NS = Not statistically significant at alpha of 0.05.

Table 8 Test for trend of DBCP and gastric cancer

\begin{tabular}{|c|c|c|c|c|c|}
\hline \multirow{2}{*}{$\begin{array}{l}\text { Time } \\
\text { of residence }\end{array}$} & \multirow{2}{*}{$\begin{array}{l}\text { Water } \\
\text { exposure according to }\end{array}$} & \multicolumn{2}{|c|}{ Multiple logistic regression* } & \multicolumn{2}{|c|}{$\begin{array}{l}\text { Mantel-Haenszel } \\
\text { procedurest }\end{array}$} \\
\hline & & Chi squared & p Value & Chi squared & p Value \\
\hline $\begin{array}{l}\text { Death } \\
\text { One year before } \\
\text { Ten years before }\end{array}$ & $\begin{array}{l}\text { Census tract } \\
\text { Water system } \\
\text { Census tract } \\
\text { Water system } \\
\text { Census tract } \\
\text { Water system }\end{array}$ & $\begin{array}{l}0.09 \\
0.47 \\
0.00 \\
1.09 \\
0.00 \\
3.49\end{array}$ & $\begin{array}{l}0.77 \\
0.49 \\
0.96 \\
0.30 \\
0.99 \\
0.06\end{array}$ & $\begin{array}{l}0.08 \\
1.04 \\
0.05 \\
2.04 \\
0.00 \\
2.03\end{array}$ & $\begin{array}{l}0.78 \\
0.31 \\
0.82 \\
0.15 \\
0.99 \\
0.16\end{array}$ \\
\hline
\end{tabular}

* + See table 7.

contamination level ranged from 1.00 to 3.05 , with no statistically significant increases. Table 8 presents the chi-squared tests for trend by DBCP level; none was statistically significant.

\section{CASE-CONTROL STUDY OF LEUKAEMIA}

Similar analyses were done for leukaemia. In examining possible confounding variables we found that agricultural workers had a relative risk of $1.71 \mathrm{p}=$ $0.24)$ for all leukaemias and a relative risk of $1.95(p=$ $0 \cdot 12$ ) for lymphatic leukaemia when compared with other county residents. Hispanic status did not appear to be a risk factor for leukaemia $(R R=0.83)$, although the effect of controlling for this was to increase the relative risk for agricultural work to 1.92.

Table 9 examines the relation between $\mathrm{DBCP}$ water contamination and risk of leukaemia. For the MantelHaenszel analysis of total leukaemias, relative risks for residents in the high DBCP group (>1.0 ppb), as defined in the DOHS study, to the low DBCP group $(<0.05 \mathrm{ppb})$ ranged from 0.74 to 1.50 , with no significant rises. Similarly, for the logistic regression analysis, relative risks for the high DBCP group ranged from 0.96 to 3.91 , with no values even approaching statistical significance. Chi-squared tests for trend between risk of leukaemia and DBCP

Table 9 Relative risk of leukaemia low exposure group $v$ high exposure group for DBCP (using multiple logistic regression and Mantel-Haenszel procedure)

\begin{tabular}{|c|c|c|c|c|c|c|c|}
\hline \multirow[b]{2}{*}{$\begin{array}{l}\text { Time } \\
\text { of residence }\end{array}$} & \multirow[b]{2}{*}{$\begin{array}{l}\text { Water exposure } \\
\text { according to }\end{array}$} & \multicolumn{3}{|c|}{ Multiple logistic regression * } & \multicolumn{3}{|c|}{ Mantel-Haenszel procedure† } \\
\hline & & $\boldsymbol{R} \boldsymbol{R}$ & $p$ & $\begin{array}{l}95 \% \text { Confidence } \\
\text { interval }\end{array}$ & $\boldsymbol{R} R$ & $p$ & $\begin{array}{l}95 \% \text { Confidence } \\
\text { interval }\end{array}$ \\
\hline $\begin{array}{l}\text { Death } \\
\text { One year before } \\
\text { Ten years before }\end{array}$ & $\begin{array}{l}\text { Census tract } \\
\text { Water system } \\
\text { Census tract } \\
\text { Water system } \\
\text { Census tract } \\
\text { Water system }\end{array}$ & $\begin{array}{l}1.01 \\
0.96 \\
1.14 \\
1.26 \\
1.01 \\
3.91\end{array}$ & $\begin{array}{l}\text { NS } \\
\text { NS } \\
\text { NS } \\
\text { NS } \\
\text { NS } \\
\text { NS }\end{array}$ & $\begin{array}{l}(0.70,1.47) \\
(0.37,2.51) \\
(0.76,1.71) \\
(0.35,4.50) \\
(0.65,1.57) \\
(0.71,21.51)\end{array}$ & $\begin{array}{l}1.42 \\
0.74 \\
1.50 \\
0.79 \\
1.24 \\
1.39\end{array}$ & $\begin{array}{l}\text { NS } \\
\text { NS } \\
\text { NS } \\
\text { NS } \\
\text { NS } \\
\text { NS }\end{array}$ & $\begin{array}{l}(0.80,2.50) \\
(0.31,1.78) \\
(0.78,2 \cdot 87) \\
(0.30,2.07) \\
(0.63,2.43) \\
(0.52,3.68)\end{array}$ \\
\hline
\end{tabular}

*+NS, see table 7. 
Table 10 Test for trend of DBCP and leukaemia

\begin{tabular}{|c|c|c|c|c|c|}
\hline \multirow{2}{*}{$\begin{array}{l}\text { Time } \\
\text { of residence }\end{array}$} & \multirow{2}{*}{$\begin{array}{l}\text { Water } \\
\text { exposure according to }\end{array}$} & \multicolumn{2}{|c|}{ Multiple logistic regression* } & \multicolumn{2}{|c|}{$\begin{array}{l}\text { Mantel-Haenszel } \\
\text { procedurest }\end{array}$} \\
\hline & & Chi squared & p Value & Chi squared & $p V a l$ \\
\hline $\begin{array}{l}\text { Death } \\
\text { One year before } \\
\text { Ten years before }\end{array}$ & $\begin{array}{l}\text { Census tract } \\
\text { Water system } \\
\text { Census tract } \\
\text { Water system } \\
\text { Census tract } \\
\text { Water system }\end{array}$ & $\begin{array}{l}0.01 \\
0.01 \\
0.41 \\
0.12 \\
0.00 \\
2.45\end{array}$ & $\begin{array}{l}0.94 \\
0.94 \\
0.52 \\
0.73 \\
0.96 \\
0.12\end{array}$ & $\begin{array}{l}1 \cdot 21 \\
0.08 \\
1.37 \\
0.10 \\
0.50 \\
1.06\end{array}$ & 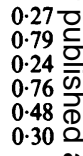 \\
\hline
\end{tabular}

*† See table 7.

Table 11 Relative risk of lymphatic leukaemia low exposure group v high exposure group for DBCP (using multiple logistico regression and Mantel-Haenszel procedure)

\begin{tabular}{|c|c|c|c|c|c|c|c|}
\hline \multirow[b]{2}{*}{$\begin{array}{l}\text { Time } \\
\text { of residence }\end{array}$} & \multirow[b]{2}{*}{$\begin{array}{l}\text { Water exposure } \\
\text { according to }\end{array}$} & \multicolumn{3}{|c|}{ Multiple logistic regression* } & \multicolumn{3}{|c|}{ Mantel-Haenszel procedure $\dagger$} \\
\hline & & $\boldsymbol{R R}$ & $p$ & $\begin{array}{l}95 \% \text { Confidence } \\
\text { interval }\end{array}$ & $\boldsymbol{R} R$ & $p$ & $\begin{array}{l}\text { 95\% Confideriee } \\
\text { interval }\end{array}$ \\
\hline $\begin{array}{l}\text { Death } \\
\text { One year before } \\
\text { Ten years before }\end{array}$ & $\begin{array}{l}\text { Census tract } \\
\text { Water system } \\
\text { Census tract } \\
\text { Water system } \\
\text { Census tract } \\
\text { Water system }\end{array}$ & $\begin{array}{l}1 \cdot 25 \\
1 \cdot 13 \\
1 \cdot 36 \\
1 \cdot 94 \\
1 \cdot 35 \\
1 \cdot 27\end{array}$ & $\begin{array}{l}\text { NS } \\
\text { NS } \\
\text { NS } \\
\text { NS } \\
\text { NS } \\
\text { NS }\end{array}$ & $\begin{array}{l}(0.68,2.29) \\
(0.22,5.88) \\
(0.73,2.54) \\
(0.25,15.39) \\
(0.71,2.58) \\
(0.02,76.58)\end{array}$ & $\begin{array}{l}3 \cdot 48 \\
1 \cdot 25 \\
2 \cdot 58 \\
2 \cdot 32 \\
1 \cdot 15 \\
1 \cdot 59\end{array}$ & $\begin{array}{l}\text { S } \\
\text { NS } \\
\text { NS } \\
\text { NS } \\
\text { NS } \\
\text { NS }\end{array}$ & $\begin{array}{l}(1.33,9.13) \\
(0.31,5 \cdot 13) \\
(0.97,6.82) \\
(0.46,11.77) \\
(0.40,3.29) \\
(0.37,6.86)\end{array}$ \\
\hline
\end{tabular}

*+NS, see table 7.

$\mathrm{S}=$ Statistically significant at alpha $=0.05$.

(table 10) were not statistically significant.

For lymphatic leukaemia, the Mantel-Haenszel analysis showed relative risks between the high and low DBCP groups ranging from $1 \cdot 15$ to 3.48 (table 11). One relative risk (census tract at time of death) was statistically significant $(p=0.01)$ by the MantelHaenszel procedure but not by logistic regression. Relative risks between the high and low DBCP groups for lymphatic leukaemia based on logistic regression analysis ranged from 1.13 to 1.94 , with no statistically significant increases. Table 12 shows the chi-squared test for trend between lymphatic leukaemia and DBCP, wherein one trend (for water system one year before death) is significant by the Mantel-Haenszel analysis but not by logistic regression.

\section{Discussion}

The purpose of the ecological correlation analyses to replicate the DOHS study' but with more complewe water quality data, an expanded period, and contiol for Hispanic proportion. We fully recognise the limit tions of the correlation analyses. All the problems associated with ecological fallacy apply to these particular analyses.

On the other hand, our approach added several dimensions to the previous DOHS examination. Firstly, the denominators in rate calculations were estimated by using several censuses with interpolation between them instead of using one single year. Secondly, age adjustment used five year grouping

Table 12 Test for trend of DBCP and lymphatic leukaemia

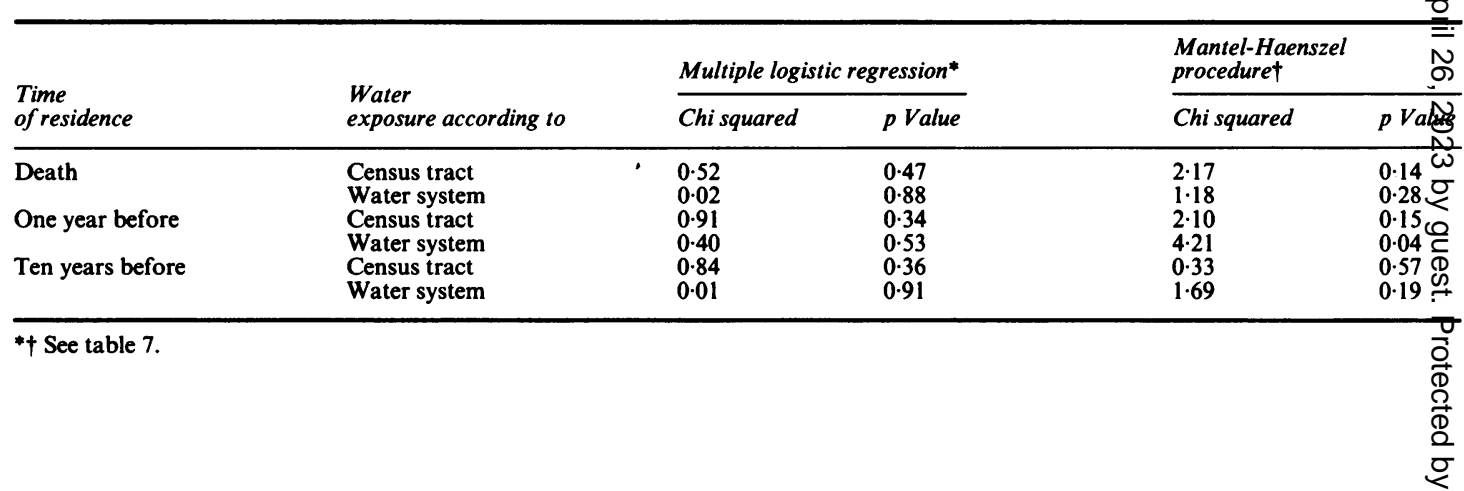


instead of 20 year intervals. Thirdly, mortality rates were adjusted for Hispanic ethnicity, a previously reported risk factor for gastric cancer. Fourthly, our investigation used more complete water quality data. Fifthly, the study period was expanded from 10 to 24 years and data were examined in five year intervals to allow analysis by temporal trend and latency. Finally, our analyses used seven categories of DBCP exposure rather than three. This reduced the magnitude of bias associated with ecological fallacy by making the groups smaller and more homogeneous, as well as reducing the chance of finding an association due to random permutation.

Although the gastric cancer and leukaemia ecological analyses were not intended as definitive studies on the relation between DBCP and death from gastric cancer or leukaemia, they do have some use in examining the relation between DBCP and gastric cancer or leukaemia. The fact that we find no association between DBCP and gastric cancer makes it even more likely that the several problems (especially confounding by Hispanic proportion) led to a spurious association in the previous DOHS study. Similarly for leukaemia, we have identified agricultural work as a confounder that was not controlled for in the previous DOHS study. Previous reports have identified farm workers as experiencing a higher risk of leukaemia.?

A more appropriate study design to investigate a problem such as this is a case-control study, taking residential histories and occupation, as well as other confounding factors, into consideration.

In any case-control study one questions the ascertainment of the cases, the selection of the controls, and the response rate of study subjects. We think that selection of the cases from deaths provided a reasonable sample of all gastric cancer or leukaemia incidence cases. Further, our study was stimulated by a study reporting an association between mortality and water quality. The selection of controls was a little more difficult. Ideally, one might prefer to select controls from all Fresno County residents alive at the time the cases died. Unfortunately, in epidemiology the ideal is not always achievable but we believe the use of all other deaths is a reasonable compromise.

In the case-control study residential history questionnaires were completed for $77.2 \%$ gastric cancer cases and $77.0 \%$ gastric cancer controls, and $76.3 \%$ leukaemia cases and $75.0 \%$ leukaemia controls (table 1). There were $2 \%$ to $3 \%$ refusals and $20 \%$ "no contacts" in both cases and controls. The main loss of information caused by non-response or refusal was the lack of any detailed occupational information, other than that listed on the death certificate. Although the risk of gastric cancer did not appear related to occupation, there is no guarantee that some bias in that regard did not occur due to non-response. For leukaemia, lack of occupational information might be a potential problem.

Our method of analysis tended to minimise potential bias caused by non-response. Had we made assumptions concerning previous address for those subjects whose only address was on the death certificate, we might have had bias in the results for the one year before or the ten years before analyses. Since, however, we omitted those people from both analyses, non-response should introduce relatively little bias, unless people who moved into the county within ten years before death had both a different risk of gastric cancer or leukaemia and a tendency to live in areas with either the highest or lowest DBCP contamination.

Since our water quality data went back only as far as 1979 , among both cases and controls there is the concern of the relation of 1979 (or later) water contamination to personal ingestion in previous years. As discussed elsewhere ${ }^{2}$ we could see no way around this problem; our only reassurance was that, relatively speaking, because of long standing agricultural patterns, the areas of greatest contamination in 1979 were likely to be the areas of greatest contamination ten years earlier as well. We were unable to estimate occupational exposure to DBCP that may have occurred among farm workers who lived in the areas of worst contamination.

In the case-control studies we could go beyond the census tract to the water system that supplied the individual's residence. We consider this an important improvement over the census tract level of analysis but not entirely free of problems, since estimates of water quality were based on a limited number of samples and several assumptions concerning open systems and uniform distribution.

One incidental finding was of some interest. In examining possible variables before testing any hypotheses concerning water contamination we found that the variable of "Hispanic surname" was a risk factor for gastric cancer in Fresno County. This confirms previous findings that Hispanics in both New Mexico and Los Angeles metropolitan areas have higher rates of gastric cancer than non-Hispanics. ${ }^{89}$ Our finding that Hispanics in Fresno County died from gastric cancer at a younger age also tends to indicate a greater susceptibility or greater exposure to some unknown factor than is experienced by the rest of the population. Because of this confounding effect, we included "Hispanic surname" as a control variable in both the Mantel-Haenszel and logistic regression analyses for gastric cancer, especially since the Hispanics tended to live in the more contaminated water areas. We are aware that our use of the extensive Bureau of Census computer listing of Hispanic sur- 
names provides opportunity for misclassification in both directions. Although we cannot measure the extent of this possible misclassification, we consider the problem minor and unlikely to bias the results.

Among all the relative risks for gastric cancer generated, there is only one that approaches statistical significance and that is the multiple logistic regression for water system ten years before death, which had a relative risk of 3.05 and a lower confidence level of $0 \cdot 95$. This finding was not confirmed by the MantelHaenszel analysis $(R R=1 \cdot 24, C I=0.49-3 \cdot 12)$ and is not supported by the ecological correlation analysis.

Similarly, we consider our data on leukaemia, and the seven strata classification of exposure and adjustment for Hispanic proportion, to be more appropriate in an ecological analysis. Because of the relatively small numbers, the rates for all leukaemia are more stable than the lymphatic leukaemia subset. In no instance do total leukaemia rates show a clear or significant trend with increasing contamination. For lymphatic leukaemia the DOHS data produce only one significant correlation and that is not confirmed by our more complete data. We conclude that there is no evidence, on the basis of ecological correlation, for any association between DBCP contamination of the water supply in Fresno County and death from leukaemia, including the lymphatic varieties.

The leukaemia case-control study failed to show any association between DBCP concentrations and the risk of leukaemia (including lymphatic). Such a relation would be indicated by either a significant rise of relative risk for the high contamination group compared with the lowest or a significant trend of risk upward with increasing potential exposure. Neither instance occurred with any consistency. Presumably, Fresno County residents' exposure to water containing DBCP began some time in the 1960s. Since radiation and benzene induced leukaemias have been reported with latency periods of less than ten years, sufficient time (about 20 years) may have now elapsed in Fresno County to detect any major effect or risk of leukaemia. We do not find any association between water contaminated with DBCP and leukaemia in Fresno County.

Both the studies on gastric cancer and leukaemia illustrate some of the problems of attempting to measure the health impact on a community of an episode of chronic contamination, especially of ground water. Clearly, in studying such questions there must be careful attention to all detail bQut especially to two issues: exposure estimates and pote tial confounding by ethnicity, occupation, or othar factors. It is of some epidemiological importance that the fairly exhaustive but non-invasive ecologicagl analysis gave results similar to the case-control approach.

We extend our special thanks to the citizens of Fresi̊ County, the California Department of Health Services, the Fresno County Department of Health, and members of our peer review committee (Sir Richard Doll of Oxford University, Professor Briâs MacMahon of Harvard University, and Professof T W Anderson of the University of British Columbial . We also thank the staff at Environmental Healm Associates, particularly Diana Tesh and Carol Klassen.

Requests for reprints to: Dr Otto Wong, Environme $\vec{b}$ tal Health Associates, 520 Third Street, Suite 208, Oakland, California 94607, USA.

\section{References}

1 Jackson RJ, Greene CJ, Thomas JT, Murphy EL, Kal\&r." J Literature review on the toxicological aspects of DBCP at epidemiological comparison of patterns of $D B C P$ drinking contamination with mortality rates from selected cancess Fresno County, California, 1970-79. Berkeley: Caliform Department of Health Services, 1982.

2 Whorton MD, Morgan RW, Wong O, Larsen S, Gordon Problems associated with collecting drinking water quality data for community studies: a case example of Fresno County. An? Public Health 1987;77:47-51.

3 Mantel N, Haenszel W. Statistical aspects of the analysis of dati from retrospective studies of disease. JNCI 1959;22:719-48.

4 Mantel N. Synthetic retrospective studies and related topies Biometrics 1963;29:470-86.

5 Prentice R. Use of the logistic model in retrospective studies. Biometrics 1976;32:599-606.

6 Prentice R, Pyke R. Logistic disease incidence models and casecontrol studies. Biometrika 1979;66:403-11.

7 Blair A, Thomas AL. Leukemia among Nebraska farmers; a deaft certificate study. Am J Epidemiol 1979;110:264-73.

8 Wilkinson GS. Gastric cancer in New Mexico counties with significant deposits of uranium. Arch Environ Health $198 \overline{3}$ 40:307-12.

9 Garabrant DH, Peters JM, Mack TM, Bernstein L. Job activities and colon cancer risk. Am J Epidemiol 1984;119:1005-14. 